\title{
Nitrogen Effects on the Essential Oil and Biomass Production of Field Grown Greek Oregano (Origanum vulgare subsp. hirtum) Populations
}

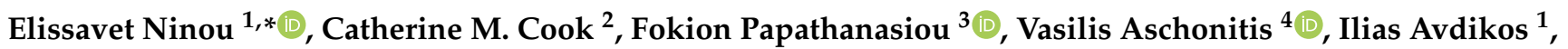 \\ Athanasios L. Tsivelikas ${ }^{5}$, Stefanos Stefanou ${ }^{1}$ (D), Parthenopi Ralli ${ }^{2}$ (D) and Ioannis Mylonas ${ }^{2, *(D)}$ \\ 1 Department of Agriculture, International Hellenic University, Sindos, 57400 Thessaloniki, Greece; \\ avdikos.elias@gmail.com (I.A.); stefst2@ihu.gr (S.S.) \\ 2 Hellenic Agricultural Organization-Dimitra, Institute of Plant Breeding and Genetic Resources, Thermi, \\ 57001 Thessaloniki, Greece; cook@nagref.gr (C.M.C.); pralli@ipgrb.gr (P.R.) \\ 3 Department of Agriculture, University of Western Macedonia, 53100 Florina, Greece; \\ fpapathanasiou@uowm.gr \\ 4 Hellenic Agricultural Organization-Dimitra, Soil and Water Resources Institute, Thermi, \\ 57001 Thessaloniki, Greece; v.aschonitis@swri.gr \\ 5 International Center for Agricultural Research in the Dry Areas (ICARDA), Al-Irfane, Rabat 10090, Morocco; \\ a.tsivelikas@cgiar.org \\ * Correspondence: lisaninou@gmail.com (E.N.); ioanmylonas@yahoo.com (I.M.)
}

Citation: Ninou, E.; Cook, C.M.; Papathanasiou, F.; Aschonitis, V.; Avdikos, I.; Tsivelikas, A.L.; Stefanou, S.; Ralli, P.; Mylonas, I. Nitrogen Effects on the Essential Oil and Biomass Production of Field Grown Greek Oregano (Origanum vulgare subsp. hirtum) Populations. Agronomy 2021, 11, 1722. https://doi.org/ 10.3390/agronomy11091722

Received: 31 July 2021

Accepted: 26 August 2021

Published: 28 August 2021

Publisher's Note: MDPI stays neutral with regard to jurisdictional claims in published maps and institutional affiliations.

Copyright: (c) 2021 by the authors. Licensee MDPI, Basel, Switzerland. This article is an open access article distributed under the terms and conditions of the Creative Commons Attribution (CC BY) license (https:// creativecommons.org/licenses/by/ $4.0 /)$.

\begin{abstract}
This study investigates the effect of different nitrogen fertilization levels on the agronomic traits of five Greek oregano populations. Nitrogen supply positively affected dry bio-mass production, with the highest accumulation recorded at $80 \mathrm{~kg} \mathrm{~N} \mathrm{ha}^{-1}$ (N2), which was $59 \%$ higher compared to the control plots (no additional nitrogen). In contrast, the essential oil content (mL $100 \mathrm{~g}^{-1} \mathrm{DW}$ ) was reduced, with the control treatment showing a $15 \%$ higher value compared to the mean value of the nitrogen treatments. However, nitrogen supply positively affected the essential oil yield ( $\mathrm{L} \mathrm{ha}^{-1}$ ), and the highest value was recorded at $80 \mathrm{~kg} \mathrm{~N} \mathrm{ha}^{-1}$, (N2), showing a $40 \%$ increase compared to the control. A wide phenotypic variation among the five populations was also observed. In the three-year analysis, the population with the highest dry biomass production was Papadates (92\% higher), that with the highest essential oil content was Vytina ( $25 \%$ higher), and the highest essential oil yield was observed for Papadates and Litochoro (57\% and 51\% higher, respectively), compared to the least yielding population. Significant interactions were also found between nitrogen levels and populations, implying that, in all cases, nitrogen levels should be specified for each population in order to optimize oregano productivity in sustainable farming systems.
\end{abstract}

Keywords: essential oil yield; genetic variation; nitrogen inputs; oregano

\section{Introduction}

Over recent decades, a growing interest in the use of medicinal and aromatic plants worldwide has been observed [1]. This increased demand has endangered the native plant resources through the uncontrolled collection of plants from the wild. Particularly, the collection of plants before seed set has a negative effect on regeneration rates and population size [2]. In order to conserve aromatic and medicinal species in their natural habitats and satisfy demand, it has become necessary to introduce them into cultivation. Thus, studies assessing the required nutritional inputs for their growth and development under cultivation conditions are needed [3-5].

Many studies to date have focused on botanical aspects of the genus Origanum, but further work is required for crop domestication and the selection of the most suitable populations for cultivation [6,7]. Greek oregano, Origanum vulgare subsp. hirtum, is an important native herb, which is widespread in most parts of the country but shows high 
variation in the yield and quality of its essential oil [8-13]. Apart from its use as a herb, oregano also has therapeutic benefits to human health due to its antioxidative, antimicrobial, and antifungal properties [13-15]. When used as a soil amendment, Oregano plants can also enhance the tolerance of other cultivated plants to soilborne diseases and consequently contribute to the increase of the yield and product quality [16]. It will be beneficial to utilize the genetic variability observed in wild oregano populations in order to select plants with optimal characteristics for introduction into cultivation, with a potential economic return as an essential commodity in food and health products.

Inorganic nitrogen is fundamental for plant nutrition and the efficient use of nitrogenous fertilizers is essential for sustainable production and yield maximization. The nitrogen management of oregano as a crop has been studied to provide information for the introduction of oregano in agricultural production [17-19]. These field studies have been conducted to assess the impact of nitrogen availability on the growth of oregano plants $[18,20,21]$ concerning cultivation practices. These have shown that nitrogen positively affects the essential oil yield production ( $\mathrm{L} \mathrm{ha}^{-1}$ ) due to increased vegetative growth [20] and harvested herbage yield $[18,19]$. Another study has examined the in vitro bio-accessibility of nitrogen using one oregano genotype [22]. Apart from the cultivation and environmental conditions [21,23-25], another critical parameter that should be considered for productivity is the genotype [23].

The objective of the present study was to evaluate the effect of the population (genotype) and nitrogen fertilization on Greek oregano production (dry biomass and essential oil) and to study their interaction under field conditions during a three-year experiment. To the best of our knowledge, even though several studies have been conducted on the effect of nitrogen fertilization on the biomass and essential oil production of oregano, these either studied only one genotype either of Greek oregano (Origanum vulgare subsp. hirtum) [18-22,25] or Egyptian oregano (Origanum syriacum L. var. bevanii) [26]. Moreover, in a case where several Greek oregano populations were used [27], these were studied under greenhouse conditions in pots. Other researchers included either one Egyptian oregano [28] genotype or three different oregano species (O. vulgare var. creticum, O. vulgare subsp.hirtum, O. vulgare var. samothraceae) [29]. Considering the above, this is the first field study that simultaneously evaluates a considerable number (5) of Greek oregano (Origanum vulgare subsp. hirtum) populations originating from diverse regions across Greece, in different levels of nitrogen fertilization. This 3-year study aspires to provide valuable information from an agronomic point of view for optimal resource use efficiency and better management of Greek oregano as a crop.

\section{Materials and Methods}

\subsection{Obtaining Plant Material}

Oregano (Origanum vulgare subsp. hirtum) seeds were collected from wild populations (from at least 40 plants from each location) from five locations in Greece: Site 1: PanagiaKavala $40^{\circ} 53^{\prime}$ N $24^{\circ} 14^{\prime}$ E; Site 2: Litochoro-Pieria $40^{\circ} 5$ N 22 $2^{\circ} 9^{\prime}$ E; Site 3: Omolio-Larisa $33^{\circ} 53^{\prime} \mathrm{N} 22^{\circ} 38^{\prime}$ E; Site 4: Papadates-Thesprotia $39^{\circ} 19^{\prime}$ N $20^{\circ} 47^{\prime}$ E; Site 5: Vytina-Arcadia $37^{\circ} 39^{\prime} \mathrm{N} 22^{\circ} 12^{\prime}$ E. Each site belongs to a different, distinct floristic region of Greece [30] with varying climatic conditions: Site 1: North East (NE); Site 2: North Central (NC); Site 3: East Central (EC); Site 4: South Pindos (SPi); Site 5: Peloponese (Pe) (Figure 1).

\subsection{Field Experiment}

Two factors were studied over three years in a randomized complete block design with three replications. The first factor was population, while the second was nitrogen dose. The first factor consisted of the five populations of O. vulgare subsp. hirtum and the second factor consisted of the four nitrogen supply levels: Control (with no added nitrogen), N1 $\left(40 \mathrm{~kg} \mathrm{~N} \mathrm{ha}^{-1}\right), \mathrm{N} 2\left(80 \mathrm{~kg} \mathrm{~N} \mathrm{ha}^{-1}\right)$ and N3 $\left(120 \mathrm{~kg} \mathrm{~N} \mathrm{ha}^{-1}\right)$. The field experiments were conducted at a farm in Omolio, Larissa ( $\left.39^{\circ} 54^{\prime} \mathrm{N}, 2^{\circ} 39^{\prime} \mathrm{E}\right)$, North Central Greece. The soil of the experimental field had the following characteristics at a depth of 0-30 cm: loam 
(43\% sand, 20\% silt, 37\% clay), pH $\left(1: 1 \mathrm{H}_{2} \mathrm{O}\right) 7.6, \mathrm{~N} 8.4 \mu \mathrm{g} \mathrm{g}^{-1}$, $\mathrm{P}$ (Olsen) $18.5 \mu \mathrm{g} \mathrm{g}^{-1}$, $\mathrm{K}^{+}$(exchangeable) $135 \mu \mathrm{g} \mathrm{g}^{-1}$ and $2.0 \%$ organic matter. Prior to planting, phosphorous fertilizer was applied $\left(80 \mathrm{~kg} \mathrm{P} \mathrm{ha}^{-1}\right)$ in the first year of the experimentation.

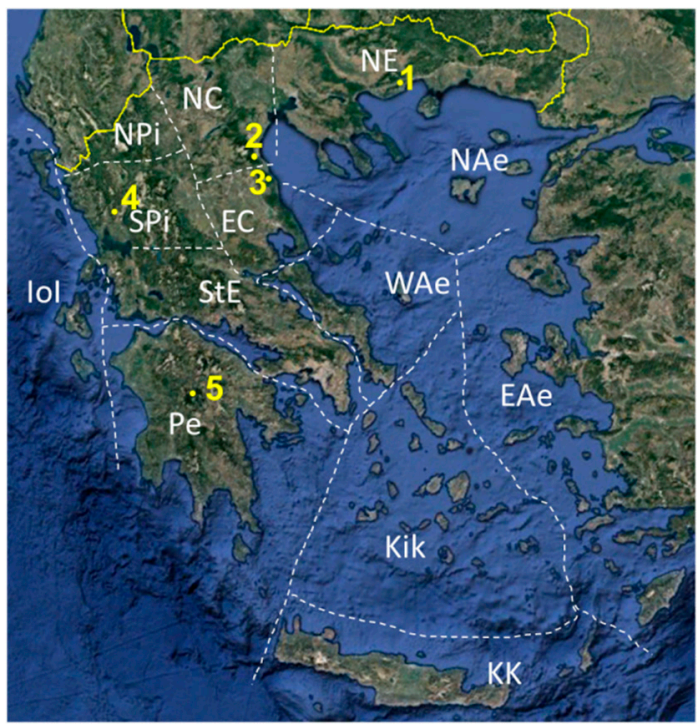

Figure 1. Map of Greece showing the five collection sites of the oregano (Origanum vulgare subsp. hirtum) seed and the distinct floristic regions of Greece, as these are designated in Flora Hellenica, adapted from Strid and Tan [30]. Site 1: Panagia-Kavala 40 $53^{\prime} \mathrm{N} 24^{\circ} 14^{\prime} \mathrm{E}$, North East (NE), Site

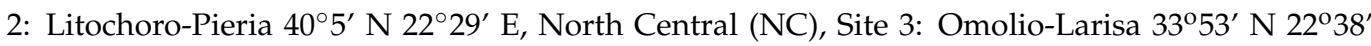
E, East Central (EC), Site 4: Papadates-Thesprotia 39 $19^{\prime}$ N $20^{\circ} 47^{\prime}$ E, South Pindos (SPi), Site 5: Vytina-Arcadia $37^{\circ} 39^{\prime} \mathrm{N} 22^{\circ} 12^{\prime}$ E, Peloponese (Pe). [31] Google. (n.d.)

Seeds were sown in a nursery (March 2008) and the most uniform seedlings with the greatest development were transplanted out in the experimental field (September 2008). Each plot consisted of four rows with a length of $2.10 \mathrm{~m}$ and with $0.75 \mathrm{~m}$ between the rows. In each row, the plant to plant distance was $0.30 \mathrm{~m}$, and each of 32 hills was overplanted to ensure survival and selection of the most robust plant. After planting, the field was irrigated twice a week at a rate of $5 \mathrm{~L} /$ plant for one month. At this point robust plant establishment was attained, and then no additional irrigation was used.

The first cultivation period (2009) was considered a period for establishing the oregano plants in the field, and herbage production was low. As each hill was overplanted, the plants were thinned in May 2010 to one plant per hill, so that there were 32 plants per plot. Weeds were controlled by applying the herbicide Terbacil (CAS No. 5902-51-2) $\left(1 \mathrm{~kg}\right.$ a.i. $\left.\mathrm{ha}^{-1}\right)$ at the end of February of each year and by hand weeding when it was necessary. Nitrogen fertilizer (ammonium nitrate, 34.5-0-0) was applied in the middle of March in 2010, 2011 and 2012. Herbage production (biomass dry weight) was determined in 2010, 2011 and 2012. The crop was harvested when approximately $80 \%$ of the plants were in full bloom, which corresponds to the stage at which oregano has its highest essential oil content. The plant stems were cut $5 \mathrm{~cm}$ from ground level, were dried in an air-circulating oven at $40{ }^{\circ} \mathrm{C}$ for 4 days and then the dry biomass was measured.

Essential oil was isolated from the flowering aerial parts from each treatment and replicate. Essential oil content was determined using a sub-sample (70 g) of the dry biomass by hydro-distillation for $3 \mathrm{~h}$ using a Clevenger-type apparatus in accordance with international guidelines [31,32]. Essential oil content was expressed as $\mathrm{mL}$ essential oil $100 \mathrm{~g}^{-1} \mathrm{DW}$. The essential oil yield $\left(\mathrm{L} \mathrm{ha}^{-1}\right)$ was calculated from the essential oil content and the dry biomass per unit area. 


\subsection{Statistical Analysis}

Analysis of variance was used to examine the relationships between dry biomass production $\left(\mathrm{Mg} \mathrm{ha}^{-1}\right)$, essential oil (EO) content (mL $\left.100 \mathrm{~g}^{-1} \mathrm{DW}\right)$ and essential oil (EO) yield $\left(\mathrm{L} \mathrm{ha}^{-1}\right)$ with respect to cultivation year $(\mathrm{Y})$, nitrogen level $(\mathrm{N})$ and population (Pop). Tukey's test $(p<0.05)$ was used to detect significant differences among the means. All statistical analyses were performed using the IBM SPSS package v. 23 (IBM Corp., New York, NY, USA, 2015) [33].

\section{Results and Discussion}

\subsection{Effect of Nitrogen Supply on Dry Biomass Production and Essential Oil}

Analysis of variance showed that there was a significant, positive effect of nitrogen supply level on dry biomass production $(p<0.001)$, and essential oil yield $\left(\mathrm{L} \mathrm{ha}^{-1}\right)$ $(p<0.001)$, and a significant, negative effect on essential oil content $(p<0.01)$, during plant growth (Table 1, Figure 2).

Table 1. Analysis of variance to examine the relationships between dry biomass production $\left(\mathrm{Mg} \mathrm{ha}^{-1}\right)$, essential oil (EO) content (mL $\left.100 \mathrm{~g}^{-1} \mathrm{DW}\right)$ and essential oil (EO) yield $\left(\mathrm{L} \mathrm{ha}^{-1}\right)$ with respect to cultivation year (Y), nitrogen level (N) and population (Pop), for all of the five Greek oregano populations (1-Panagia, 2-Litochoro, 3-Omolio, 4-Papadates, 5Vytina) combined, grown at four different nitrogen supply levels (control, N1, N2, N3, that correspond to 0, 40, 80 and $120 \mathrm{~kg} \mathrm{~N} \mathrm{ha}^{-1}$, respectively) and measured over a three-year period (2010-2012).

\begin{tabular}{cccccccc}
\hline Mean Squares & Year (Y) & Nitrogen (N) & Population (Pop) & $\mathbf{Y} \times \mathbf{N}$ & $\mathbf{Y} \times$ Pop & $\mathbf{N} \times \mathbf{P o p}$ & $\mathbf{Y} \times \mathbf{N} \times$ Pop \\
\hline Dry biomass & $* * *$ & $* * *$ & $* * *$ & NS & $* *$ & $* * *$ & NS \\
EO content & $* * *$ & $* *$ & $* *$ & NS & $* *$ & $* *$ & NS \\
EO yield & $* * *$ & $* *$ & $* *$ & $* *$ & $* *$ & NS \\
\hline
\end{tabular}

NS, non-significant, ${ }^{* *} p<0.01,{ }^{* * *} p<0.001$.
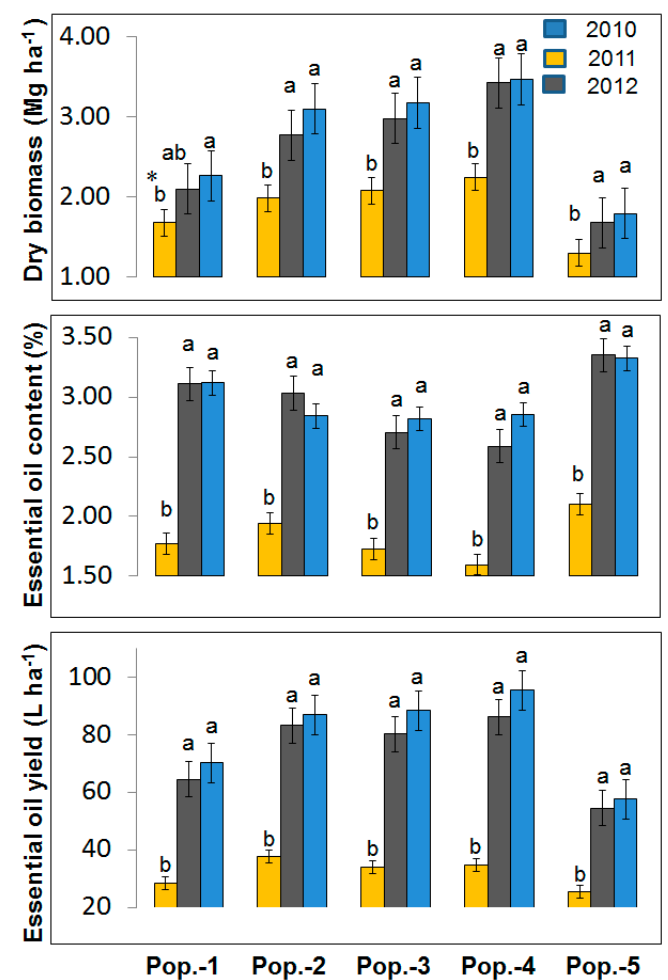

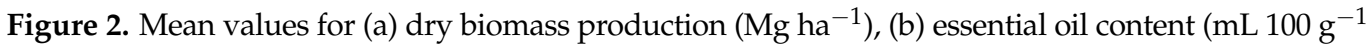
$\mathrm{DW}$ ) and (c) essential oil yield $\left(\mathrm{L} \mathrm{ha}^{-1}\right)$ for each of the oregano populations (1-Panagia, 2-Litochoro, 3-Omolio, 4-Papadates, 5-Vytina), averaged for the four nitrogen fertilization levels (control, N1, N2, N3, that correspond to $0,40,80$ and $120 \mathrm{~kg} \mathrm{~N} \mathrm{ha}^{-1}$, respectively), with respect to each cultivation year. ${ }^{*}$ For each population mean values $( \pm$ S.E.) followed by different letters are significantly different at $p<0.05$. 
More specifically, the highest dry biomass production $\left(2.80 \mathrm{Mg} \mathrm{ha}^{-1}\right)$ was recorded at the $\mathrm{N} 2$ level $\left(80 \mathrm{~kg} \mathrm{~N} \mathrm{ha}^{-1}\right.$ ) for the three-year mean, although this value was not significantly different from the value $\left(2.74 \mathrm{Mg} \mathrm{ha}^{-1}\right.$ ) at N3 (Table 2). This was 59\% greater than the dry biomass production of the control, where no additional fertilizer was applied.

Table 2. The effect of different nitrogen fertilization levels (control, N1, N2, N3, that correspond to 0 , 40,80 and $120 \mathrm{~kg} \mathrm{~N} \mathrm{ha}^{-1}$, respectively) on the mean dry biomass production $\left(\mathrm{Mg} \mathrm{ha}^{-1}\right)$, essential oil content (mL $\left.100 \mathrm{~g}^{-1} \mathrm{DW}\right)$ and essential oil yield $\left(\mathrm{L} \mathrm{ha}^{-1}\right)$ of all of the five Greek oregano populations combined (1-Panagia, 2-Litochoro, 3-Omolio, 4-Papadates, 5-Vytina), for each cultivation year and averaged for the three-year period.

\begin{tabular}{|c|c|c|c|}
\hline $\begin{array}{c}\text { Treatment } \\
\text { (Nitrogen Level) }\end{array}$ & $\begin{array}{l}\text { Dry Biomass } \\
\left(\mathrm{Mg} \mathrm{ha}^{-1}\right)\end{array}$ & $\begin{array}{l}\text { Essential Oil Content } \\
\quad\left(\mathrm{mL} 100 \mathrm{~g}^{-1} \mathrm{DW}\right)\end{array}$ & $\begin{array}{l}\text { Essential Oil Yield } \\
\left(\mathrm{L} \mathrm{ha}^{-1}\right)\end{array}$ \\
\hline \multicolumn{4}{|c|}{2010} \\
\hline Control & $1.18 \mathrm{c}^{\dagger} \pm 0.08$ & $2.23 a \pm 0.11$ & $25.45 b \pm 1.26$ \\
\hline $\mathrm{N}_{1}$ & $1.83 b \pm 0.10$ & $1.80 \mathrm{~b} \pm 0.05$ & $32.41 \mathrm{a} \pm 1.38$ \\
\hline $\mathrm{N}_{2}$ & $2.22 \mathrm{a} \pm 0.13$ & $1.63 b \pm 0.07$ & $35.24 \mathrm{a} \pm 1.66$ \\
\hline $\mathrm{N}_{3}$ & $2.17 \mathrm{a} \pm 0.14$ & $\begin{array}{c}1.65 b \pm 0.06 \\
2011\end{array}$ & $35.18 \mathrm{a} \pm 1.94$ \\
\hline Control & $1.92 c^{\dagger} \pm 0.12$ & $3.13 \mathrm{a} \pm 0.13$ & $58.24 c \pm 2.04$ \\
\hline $\mathrm{N}_{1}$ & $2.51 b \pm 0.16$ & $2.99 \mathrm{ab} \pm 0.08$ & $73.61 b \pm 3.62$ \\
\hline $\mathrm{N}_{2}$ & $3.02 \mathrm{a} \pm 0.23$ & $2.85 b \pm 0.09$ & $83.58 \mathrm{a} \pm 4.52$ \\
\hline \multicolumn{3}{|r|}{2012} & $79.87 \mathrm{ab} \pm 5.41$ \\
\hline Control & $2.05 c^{\dagger} \pm 0.14$ & $3.23 a \pm 0.12$ & $64.03 c \pm 2.47$ \\
\hline $\mathrm{N}_{1}$ & $2.66 b \pm 0.16$ & $3.01 b \pm 0.07$ & $78.84 b \pm 3.32$ \\
\hline $\mathrm{N}_{2}$ & $3.16 \mathrm{a} \pm 0.22$ & $2.85 b \pm 0.07$ & $88.33 a \pm 5.03$ \\
\hline $\mathrm{N}_{3}$ & $3.15 a \pm 0.28$ & $2.87 \mathrm{~b} \pm 0.07$ & $87.99 a \pm 6.24$ \\
\hline \multicolumn{4}{|c|}{ Three-year mean } \\
\hline Control & $1.72 c^{\dagger} \pm 0.09$ & $2.87 a \pm 0.10$ & $49.24 \mathrm{c} \pm 2.80$ \\
\hline $\mathrm{N}_{1}$ & $2.33 b \pm 0.10$ & $2.60 b \pm 0.09$ & $61.62 b \pm 3.55$ \\
\hline $\mathrm{N}_{2}$ & $2.80 \mathrm{a} \pm 0.13$ & $2.44 \mathrm{c} \pm 0.10$ & $69.05 a \pm 4.27$ \\
\hline $\mathrm{N}_{3}$ & $2.74 \mathrm{a} \pm 0.15$ & $2.46 c \pm 0.10$ & $67.68 \mathrm{a} \pm 4.46$ \\
\hline
\end{tabular}

${ }^{\dagger}$ Means followed by the same letter in a column are not significantly different (Tukey's test, $p<0.05$ ).

However, it was observed that the increased nitrogen supply reduced the essential oil content of the dry biomass, with the highest content $\left(2.87 \mathrm{~mL} 100 \mathrm{~g}^{-1} \mathrm{DW}\right)$ found in the control (no additional nitrogen) and the lowest value $\left(2.44 \mathrm{~mL} 100 \mathrm{~g}^{-1} \mathrm{DW}\right)$ at the N2 level $\left(80 \mathrm{~kg} \mathrm{~N} \mathrm{ha}^{-1}\right.$ ) (Table 2$)$. The control essential oil content had a $15 \%$ higher value compared to the mean value of the nitrogen treatments (N1, N2 and N3).

The essential oil yield ( $\mathrm{L} \mathrm{ha}^{-1}$ ) was positively affected by increasing nitrogen supply. The highest value for the three-year mean $\left(69.1 \mathrm{~L} \mathrm{ha}^{-1}\right)$ was recorded at supply level N2 $\left(80 \mathrm{~kg} \mathrm{~N} \mathrm{ha}^{-1}\right)$ and was $40 \%$ higher than the control $\left(49.2 \mathrm{~L} \mathrm{ha}^{-1}\right)$. There was no significant difference in the essential oil yield values at the N2 and N3 levels (Table 2). The effect of nitrogen fertilization was similar for all the years of experimentation on all the recorded variables since $\mathrm{Y} \times \mathrm{N}$ interactions were not significant (Table 1 ). However, it was observed that in the first year of the experimentation, all the examined parameters had lower values compared to those of the second and third years (Table 3).

Although the impact of nitrogen management in the field has been studied extensively in traditionally cultivated species, only some recent studies have investigated the impact of nitrogen of Greek oregano on growth and productivity in a farming system from an agronomic point of view $[18,19,21,25]$. Previous studies on the effect of nitrogen supply on oregano have also reported increases in the dry biomass production of a Greek oregano population in the field, proposing that a minimum nitrogen supply could be beneficial to increase economic output with respect to the harvested yield $[21,25]$. This also affected positively the essential oil yield [19] and that is also reported as a tendency by other researchers [18]. In addition, similar increases in the dry biomass production with nitrogen supply have been reported in greenhouse studies using several Greek oregano populations $[12,29]$ and other related taxa, such as 0 . syriacum $[26,28]$. Therefore, although wild Greek oregano is adapted to the hot, dry climate and low fertile soils of the Mediter- 
ranean environments, in the case of commercial agriculture, where the produced quantity is connected with economic output, oregano can efficiently utilize nitrogen fertilization and the factors affecting this should be studied in more detail. As a perennial crop, depletion of nitrogen resources can occur since a significant amount of dry biomass is removed from the field, which according to several studies, is estimated to be up to $4 \mathrm{Mg} \mathrm{ha}^{-1}[20,24,25]$.

Table 3. Mean dry biomass production $\left(\mathrm{Mg} \mathrm{ha}^{-1}\right)$, essential oil content ( $\left.\mathrm{mL} 100 \mathrm{~g}^{-1} \mathrm{DW}\right)$ and essential oil yield ( $\mathrm{L} \mathrm{ha}^{-1}$ ), of all of the five Greek oregano populations combined (1-Panagia, 2Litochoro, 3-Omolio, 4-Papadates, 5-Vytina), grown at four different nitrogen supply levels (control, $\mathrm{N} 1, \mathrm{~N} 2, \mathrm{~N} 3$, that correspond to $0,40,80$ and $120 \mathrm{~kg} \mathrm{~N} \mathrm{ha}^{-1}$, respectively), for each cultivation year and averaged for the three-year period.

\begin{tabular}{|c|c|c|c|}
\hline Year & $\begin{array}{l}\text { Dry Biomass } \\
\left(\mathrm{Mg} \mathrm{ha}^{-1}\right)\end{array}$ & $\begin{array}{l}\text { Essential Oil Content } \\
\quad\left(\mathrm{mL} 100 \mathrm{~g}^{-1} \mathrm{DW}\right)\end{array}$ & $\begin{array}{l}\text { Essential Oil Yield } \\
\left(\mathrm{L} \mathrm{ha}^{-1}\right)\end{array}$ \\
\hline 2010 & $1.85 \mathrm{~b}^{\dagger} \pm 0.08$ & $1.83 b \pm 0.05$ & $32.07 \mathrm{~b} \pm 0.93$ \\
\hline 2011 & $2.59 \mathrm{a} \pm 0.11$ & $2.96 a \pm 0.05$ & $73.83 a \pm 2.36$ \\
\hline 2012 & $2.75 a \pm 0.12$ & $2.99 \mathrm{a} \pm 0.05$ & $79.79 \mathrm{a} \pm 2.55$ \\
\hline Three-year mean & $2.40 \pm 0.07$ & $2.59 \pm 0.05$ & $61.90 \pm 1.98$ \\
\hline
\end{tabular}

${ }^{\dagger}$ Means followed by the same letter in a column are not significantly different (Tukey's test, $p<0.05$ ).

Some studies have also reported a reduction in the essential oil content after nitrogen supply under greenhouse conditions in Greek oregano [12,29] and Egyptian oregano $O$. syriacum var. aegyptiacum [28]. The reduction of the essential content recorded due to the dilution effect has also been reported by other researchers in a field experiment [19]. However, in other field experiments, either no nitrogen supply effect was observed on the essential oil content of O. vulgare subsp. hirtum [20], or a positive nitrogen supply effect was observed on the essential oil content of O. syriacum var. bevanii [26].

Dry biomass production and essential oil content are critical agronomic parameters, however, the parameter derived from them, the essential oil yield ( $\mathrm{L} \mathrm{ha}^{-1}$ ), is that directly linked with the commercial agricultural product. While in this study the essential oil content of the oregano crop showed a decrease with increasing nitrogen supply, probably due to the dilution effect [19], the essential oil yield $\left(\mathrm{L} \mathrm{ha}^{-1}\right)$ actually increased as a result of the positive effect on dry biomass production. Similar positive effects of nitrogen supply on essential oil yield have also been reported for both field grown O. vulgare subsp. hirtum [18-20] and O. syriacum var. bevanii [26] populations, and greenhouse grown $O$. vulgare subsp. hirtum [12], O. vulgare var. creticum, O. vulgare subsp. hirtum, and O. vulgare var. samothrake [29] and O. syriacum var. aegyptiacum populations [28].

Finally, an age-effect on productivity has also been reported by Sotiropoulou and Karamanos [20]. According to Goliaris [34], as a perennial crop, oregano gradually builds its productive structure and reaches its maximum potential from the third year onwards. It has also been observed that the essential oil production was much higher in the second growing season [19].

\subsection{Effect of the Population on Dry Biomass Production and Essential Oil}

The five oregano populations studied had different dry biomass production, essential oil content, and essential oil yield $\left(\mathrm{L} \mathrm{ha}^{-1}\right)$ for all the years of the experimentation (Tables 1 and 4). The Papadates population had the highest dry biomass production (3.04 $\mathrm{Mg} \mathrm{ha}^{-1}$ ), which was about $36 \%$ higher compared to the average production of the other populations (Table 1). The Panagia and Vytina populations had the lowest dry biomass production (2.01 and $1.58 \mathrm{Mg} \mathrm{ha}^{-1}$, respectively), being lower by $16 \%$ and $34 \%$, compared to the three-year mean $\left(2.40 \mathrm{Mg} \mathrm{ha}^{-1}\right.$ ) of the experiment (Tables 3 and 4 ). In the three-year analysis, Papadates had a dry biomass value $92 \%$ higher than the least yielding population. 
Table 4. Mean dry biomass production ( $\left.\mathrm{Mg} \mathrm{ha}^{-1}\right)$, essential oil content ( $\mathrm{mL} 100 \mathrm{~g}^{-1} \mathrm{DW}$ ) and essential oil yield ( $\mathrm{L} \mathrm{ha}^{-1}$ ) of each of the five Greek oregano populations, averaged for the four nitrogen fertilization levels (control, N1, N2, N3, that correspond to 0, 40, 80 and $120 \mathrm{~kg} \mathrm{~N}^{-1}$, respectively), for each cultivation year and averaged for the three-year period.

\begin{tabular}{|c|c|c|c|c|c|c|c|c|c|c|c|c|}
\hline \multirow[t]{2}{*}{ Population } & \multicolumn{4}{|c|}{ Dry Biomass (Mg ha $\left.{ }^{-1}\right)$} & \multicolumn{4}{|c|}{$\begin{array}{l}\text { Essential Oil Content } \\
\left(\mathrm{mL} 100 \mathrm{~g}^{-1} \mathrm{DW}\right)\end{array}$} & \multicolumn{4}{|c|}{$\begin{array}{c}\begin{array}{c}\text { Essential Oil Yield } \\
\left(\mathrm{L} \mathrm{ha}^{-1}\right)\end{array} \\
\end{array}$} \\
\hline & 2010 & 2011 & 2012 & $\begin{array}{l}\text { Three-Year } \\
\text { Mean }\end{array}$ & 2010 & 2011 & 2012 & $\begin{array}{l}\text { Three-Year } \\
\text { Mean }\end{array}$ & 2010 & 2011 & 2012 & $\begin{array}{l}\text { Three-Year } \\
\text { Mean }\end{array}$ \\
\hline 1 Panagia & $1.67 \mathrm{~b}^{+} \pm 0.12$ & $2.09 c \pm 0.10$ & $2.26 c \pm 0.09$ & $2.01 c \pm 0.07$ & $1.77 \mathrm{bc} \pm 0.09$ & $3.11 \mathrm{ab} \pm 0.05$ & $3.12 \mathrm{a} \pm 0.05$ & $2.67 \mathrm{~b} \pm 0.11$ & $28.54 b \pm 1.26$ & $64.63 b \pm 2.38$ & $70.23 c \pm 2.54$ & $54.46 c \pm 3.34$ \\
\hline 2 Litochoro & $1.98 \mathrm{ab} \pm 0.13$ & $2.77 \mathrm{~b} \pm 0.14$ & $3.09 b \pm 0.17$ & $2.61 b \pm 0.11$ & $1.94 \mathrm{ab} \pm 0.08$ & $3.03 b \pm 0.05$ & $2.84 \mathrm{~b} \pm 0.06$ & $2.61 b \pm 0.09$ & $37.63 a \pm 1.73$ & $83.39 a \pm 3.51$ & $87.03 b \pm 3.80$ & $69.35 \mathrm{ab} \pm 4.19$ \\
\hline 3 Omolio & $2.07 a \pm 0.17$ & $2.97 \mathrm{~b} \pm 0.18$ & $3.17 \mathrm{ab} \pm 0.20$ & $2.74 b \pm 0.13$ & $1.72 b c \pm 0.10$ & $2.70 c \pm 0.04$ & $2.82 b \pm 0.05$ & $2.42 \mathrm{c} \pm 0.09$ & $34.10 \mathrm{a} \pm 1.67$ & $80.33 a \pm 4.99$ & $88.46 b \pm 4.68$ & $67.63 b \pm 4.64$ \\
\hline 4 Papadates & $2.24 a \pm 0.21$ & $3.42 \mathrm{a} \pm 0.30$ & $3.46 a \pm 0.32$ & $3.04 a \pm 0.18$ & $1.60 c \pm 0.06$ & $2.59 \mathrm{c} \pm 0.08$ & $2.85 b \pm 0.10$ & $2.34 \mathrm{c} \pm 0.10$ & $34.58 a \pm 2.50$ & $86.37 a \pm 5.98$ & $95.58 \mathrm{a} \pm 6.41$ & $72.18 \mathrm{a} \pm 5.41$ \\
\hline 5 Vytina & $1.29 \mathrm{c} \pm 0.11$ & $1.67 \mathrm{~d} \pm 0.10$ & $1.78 \mathrm{~d} \pm 0.11$ & $1.58 \mathrm{~d} \pm 0.07$ & $2.10 \mathrm{a} \pm 0.16$ & $3.35 a \pm 0.16$ & $3.32 \mathrm{a} \pm 0.14$ & $2.93 a \pm 0.13$ & $25.48 b \pm 0.84$ & $54.42 \mathrm{c} \pm 1.43$ & $57.68 \mathrm{~d} \pm 1.96$ & $45.86 \mathrm{~d} \pm 2.56$ \\
\hline
\end{tabular}

${ }^{\dagger}$ Means followed by the same letter in a column are not significantly different (Tukey's test, $\mathrm{p}<0.05$ ). 
The three-year mean essential oil content ranged from 2.34 (Papadates) to 2.93 (Vytina) $\mathrm{mL} 100 \mathrm{~g}^{-1} \mathrm{DW}$ (Table 4). The highest essential oil content (Vytina) was 25\% higher than the Papadates population. The three-year mean essential oil yield ranged from 45.86 (Vytina) to 72.18 (Papadates) $\mathrm{L} \mathrm{ha}^{-1}$. The value for the Papadates population was not significantly different from that of Litochoro, at $69.35 \mathrm{~L} \mathrm{ha}^{-1}$, with both showing an essential oil yield more than $50 \%$ above that of Vytina population (Tables 1 and 4 ).

Finally, a year and population $(\mathrm{Y} \times \mathrm{Pop})$ interaction was detected for the essential oil content (mL $\left.100 \mathrm{~g}^{-1} \mathrm{DW}\right)(p<0.001)$, and the essential oil yield ( $\left.\mathrm{L} \mathrm{ha}^{-1}\right)(p<0.01)$, showing the effect of the age of the crop on these two parameters, which increase with increasing age, for the examined populations (Tables 1-3, Figure 2).

The genotype decisively affects the quality and productivity of oregano species [23]. The five Greek oregano populations studied here showed significant phenotypic variation in dry biomass production, essential oil content, and essential oil yield ( $\left.\mathrm{L} \mathrm{ha}^{-1}\right)$. In previous studies on wild populations of $O$. vulgare subsp. hirtum, from locations throughout Greece, variations in dry biomass production and essential oil content have been reported $[8,10,11,27,35]$.

In this study, the population with the highest dry biomass production, Papadates, had the lowest essential oil content. In contrast, the population with the highest essential oil content, Vytina, had the lowest dry biomass production indicating that the two parameters were inversely correlated. These two populations with high dry biomass and essential oil content characteristics could be used in a network of crosses to give desirable progeny, useful as a starting material in a plant breeding program. Wild oregano populations constitute the primary gene pool, which according to Fehr [36] constitutes one of the most important sources of genetic variation. Moreover, the two populations, Papadates and Litochoro, which show the highest essential oil yields $\left(72.18 \mathrm{~L} \mathrm{ha}^{-1}\right.$ and $69.35 \mathrm{~L} \mathrm{ha}^{-1}$, respectively), could be examined for direct introduction into commercial cultivation.

\subsection{Analysis of the Interaction between the Nitrogen Supply Level and Population $(N \times$ Pop $)$}

Analysis of variance showed that there was an interaction between the nitrogen supply level and population $(\mathrm{N} \times$ Pop), which was significant $(p<0.001)$ with respect to dry biomass production, essential oil content, and essential oil yield ( $\mathrm{L} \mathrm{ha}^{-1}$ ) (Table 1), meaning that the five populations were affected to different extents by nitrogen supply (Figure 3). More specifically, it was observed that while the N1 nitrogen supply level $\left(40 \mathrm{~kg} \mathrm{~N} \mathrm{ha}^{-1}\right)$ positively affected the dry biomass production and essential oil yield of all the five populations and was maximal for the Panagia and Vytina populations, the dry biomass production and essential oil yield of the Litochoro and Omolio populations was maximal at $\mathrm{N} 2\left(80 \mathrm{~kg} \mathrm{~N} \mathrm{ha}^{-1}\right)$, while those of the Papadates population were maximal at level N3 $\left(120 \mathrm{~kg} \mathrm{~N} \mathrm{ha}^{-1}\right)$. There appeared to be a negative effect of $120 \mathrm{~kg} \mathrm{~N} \mathrm{ha}^{-1}$ on these parameters for the Litochoro and Omolio populations (Figure 3).

In contrast, increased nitrogen supply level had a significant, negative effect on essential oil content $(p<0.001)$ (Table 1 , Figure 3). More specifically, even a small increase of nitrogen availability at level $\mathrm{N} 1\left(40 \mathrm{~kg} \mathrm{~N} \mathrm{ha}^{-1}\right)$ reduced the essential oil content of all populations. At the $\mathrm{N} 2$ level $\left(80 \mathrm{~kg} \mathrm{~N} \mathrm{ha}^{-1}\right)$, essential oil content was further reduced for the Litochoro, Omolio, Papadates and Vytina populations, while at level N3 (120 kg N ha $\left.{ }^{-1}\right)$, only the Vytina population showed a further reduction in essential oil content (Figure 3).

The study of the genotype and environment interaction plays an essential role in evaluating genotypes, and it can contribute to the increase in yield of important cultivated species by $25-45 \%[37,38]$. However, the interaction of the oregano population and nitrogen supply has only been investigated in one study under greenhouse conditions [12]. Significant nitrogen and population $(\mathrm{N} \times$ Pop) interaction was recorded in the current study for all the recorded parameters, indicating that oregano plants require nitrogen supply to maximize the economic results. Still, this level was differentiated for each of the populations used in the study. Similar results were reported by Ninou et al. [12] for the $\mathrm{G} \times \mathrm{E}(\mathrm{E}=$ nitrogen $)$ effects in Greek oregano populations under greenhouse conditions. 
Thus, it follows that nitrogen supplies should be specified for each population in order to maximize oregano productivity.
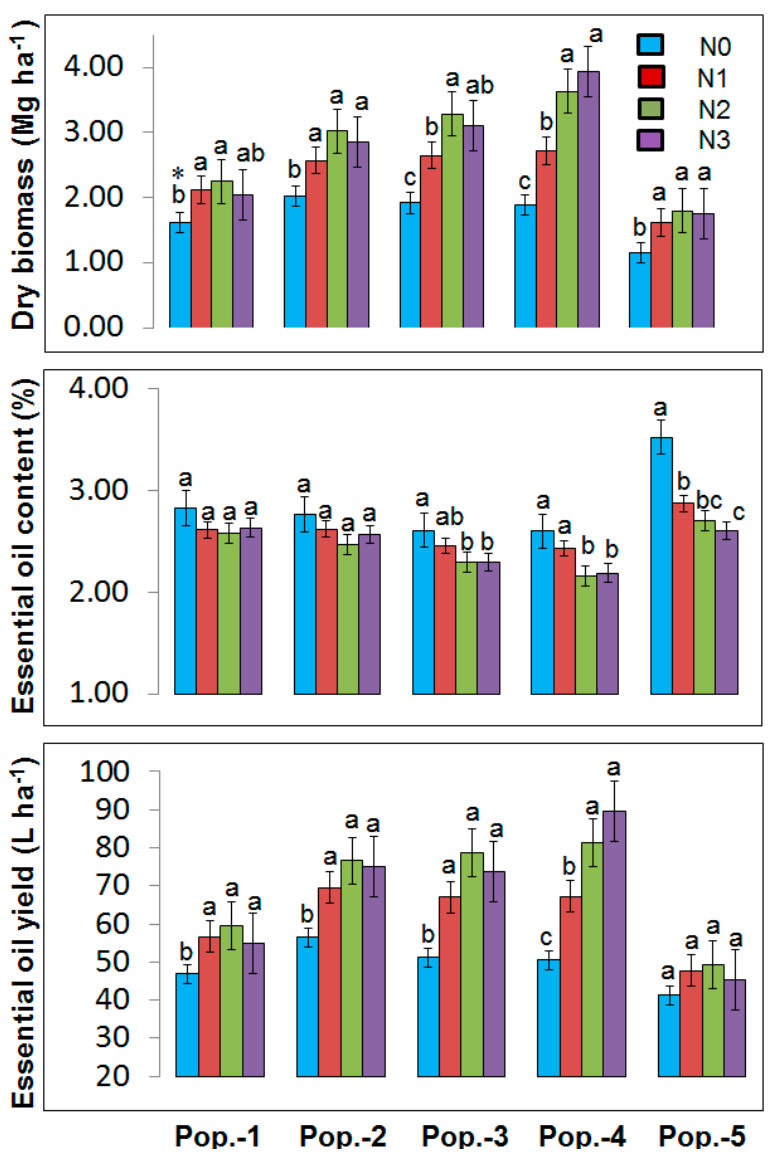

Figure 3. Mean values for (a) dry biomass production $\left(\mathrm{Mg} \mathrm{ha}^{-1}\right)$, (b) essential oil content ( $\mathrm{mL} 100 \mathrm{~g}^{-1}$ DW) and (c) essential oil yield $\left(\mathrm{L} \mathrm{ha}^{-1}\right)$ for each of the oregano populations (1-Panagia, 2-Litochoro, 3-Omolio, 4-Papadates, 5-Vytina), averaged for the three cultivation years, with respect to each of the nitrogen fertilization levels (control, N1, N2, N3, that correspond to 0, 40, 80 and $120 \mathrm{~kg} \mathrm{~N}$ ha $^{-1}$, respectively). * For each population mean values $( \pm$ S.E.) followed by different letters are significantly different at $p<0.05$.

\section{Conclusions}

The dry biomass production $\left(\mathrm{Mg} \mathrm{ha}^{-1}\right)$ and essential oil yield $\left(\mathrm{L} \mathrm{ha}^{-1}\right)$ of field grown oregano (Origanum vulgare subsp. hirtum) were positively affected (up to $59 \%$ and $40 \%$, respectively) by the application of nitrogen fertilizer up to $80 \mathrm{~kg} \mathrm{~N} \mathrm{ha}^{-1}$, although the essential oil content was reduced by up to $18 \%$ at this nitrogen supply level.

The effects of nitrogen fertilization were similar throughout the 3-year experimentation, indicating that nitrogen supply can have a beneficial role in commercial agriculture, even though Greek oregano is adapted to the hot, dry, and low fertile soils of the Mediterranean environment.

Significant phenotypic variation was found among the five oregano populations for dry biomass, essential oil content and yield. At least two of the studied populations, one with high dry biomass production (Papadates) and the other with high essential oil content (Vytina) could be used in a network of crosses to give useful starting material in a plant breeding program aiming at the production of new oregano cultivars. A nitrogen supply by population interaction was recorded for all the studied parameters. This means that, while oregano plants require nitrogen supply to maximize economic return, this is different and should be specified for each population to maximize agricultural farm production. 
Author Contributions: Conceptualization, E.N., I.M., F.P.; investigation, E.N., I.M., F.P., A.L.T. and C.M.C.; data curation, E.N., I.M., F.P., C.M.C., V.A., I.A., A.L.T., S.S., and P.R.; writing-original draft preparation, E.N., I.M, C.M.C., V.A., and I.A.; writing-review and editing, E.N., I.M., F.P., C.M.C., V.A., I.A., A.L.T., S.S., and P.R.; visualization, E.N., I.M.; supervision, E.N., I.M., and C.M.C.; Methodology E.N., I.M., F.P., C.M.C., V.A., I.A., A.L.T., S.S., and P.R. All authors have read and agreed to the published version of the manuscript.

Funding: There was no specific funding for this research.

Acknowledgments: This research did not receive any specific grant from funding agencies in the public, commercial, or not-for-profit sectors.

Conflicts of Interest: The authors declare no conflict of interest.

\section{References}

1. WHO. WHO Global Report on Traditional and Complementary Medicine 2019; World Health Organization: Geneva, Switzerland, 2019.

2. Abbad, A.; Belaqziz, R.; Bekkouche, K.; Markouk, M. Influence of temperature and water potential on laboratory germination of two Moroccan endemic thymes: Thymus maroccanus Ball. and Thymus broussonetti Boiss. Afr. J. Agric. Res. 2011, 6, 4740-4745.

3. Jamali, C.A.; Kastrati, A.; Bekkouche, K.; Hassani, L.; Wohlmuth, H.; Leach, D.; Abbad, A. Cultivation and the application of inorganic fertilizer modifies essential oil composition in two Moroccan species of Thymus. Ind. Crops Prod. 2014, 62, 113-118. [CrossRef]

4. Chrysargyris, A.; Xylia, P.; Botsaris, G.; Tzortzakis, N. Antioxidant and antibacterial activities, mineral and essential oil composition of spearmint (Mentha spicata L.) affected by the potassium levels. Ind. Crops Prod. 2017, 103, 202-212. [CrossRef]

5. Vilanova, C.M.; Coelh, K.P.; Luz, T.R.S.A.; Silveira, D.P.B.; Coutinho, D.F.; de Moura, E.G. Effect of different water application rates and nitrogen fertilisation on growth and essential oil of clove basil (Ocimum gratissimum L.). Ind. Crops Prod. 2018, 125, 186-197. [CrossRef]

6. De Mastro, G. Crop domestication and variability within accessions of Origanum genus. In Oregano, Proceedings of the IPGRI International Workshop, Rome, Italy, 8-12 May 1996; Padulosi, S., Ed.; CIHEAM: Bari, Italy, 1997; pp. $34-48$.

7. Stefanaki, A.; Cook, C.M.; Lanaras, T.; Kokkini, S. The Oregano plants of Chios Island (Greece): Essential oils of Origanum onites L. growing wild in different habitats. Ind. Crops Prod. 2016, 82, 107-113. [CrossRef]

8. Vokou, D.; Vareltzidou, S.; Katinakis, P. Effects of aromatic plants on potato storage: Sprout suppression and antimicrobial activity. Agric. Ecosyst. Environ. 1993, 47, 223-235. [CrossRef]

9. Kokkini, S.; Karousou, R.; Vokou, D. Pattern of geographic variation of Origanum vulgare trichomes and essential oil content in Greece. Bioch. Syst. Ecol. 1994, 22, 517-528. [CrossRef]

10. Kokkini, S. Taxonomy, diversity and distribution of Origanum species. In Oregano, Proceedings of the IPGRI International Workshop, Rome, Italy, 8-12 May 1996; Padulosi, S., Ed.; CIHEAM: Bari, Italy, 1997; pp. 2-12.

11. Gavalas, P.N.; Kalburtji, K.L.; Kokkini, S.; Mamolos, A.P.; Veresoglou, D. Ecotypic variation in plant characteristics for Origanum vulgare subsp. hirtum populations. Bioch. Syst. Ecol. 2011, 39, 562-569. [CrossRef]

12. Ninou, E.G.; Paschalidis, K.A.; Mylonas, I.G.; Vasilikiotis, C.; Mavromatis, A.G. The effect of genetic variation and nitrogen fertilization on productive characters of Greek oregano. Acta Agric. Scand. Sect. B-Soil Plant Sci. 2017, 67, 372-379. [CrossRef]

13. Węglarz, Z.; Kosakowska, O.; Przybył, J.L.; Pióro-Jabrucka, E.; Bączek, K. The Quality of Greek Oregano (O. vulgare L. subsp. hirtum (Link) Ietswaart) and Common Oregano (O. vulgare L. subsp. vulgare) Cultivated in the Temperate Climate of Central Europe. Foods 2020, 9, 1671. [CrossRef] [PubMed]

14. Gavaric, N.; Mozina, S.S.; Kladar, N.V.; Bozin, B. Chemical profile, antioxidant and antibacterial activity of thyme and oregano essential oils, thymol and carvacrol and their possible synergism. J. Essent. Oil Bear. Plants 2015, 18, 1013-1021. [CrossRef]

15. Adame-Gallegos, J.R.; Andrade-Ochoa, S.; Nevarez-Moorillon, G.V. Potential use of Mexican oregano essential oil against parasite, fungal and bacterial pathogens. J. Essent. Oil Bear. Plants 2016, 19, 553-567. [CrossRef]

16. Kadoglidou, K.; Chatzopoulou, P.; Maloupa, E.; Kalaitzidis, A.; Ghoghoberidze, S.; Katsantonis, D. Mentha and Oregano Soil Amendment Induces Enhancement of Tomato Tolerance against Soilborne Diseases, Yield and Quality. Agronomy 2020, 10, 406. [CrossRef]

17. Bonfanti, C.; Ianni, R.; Mazzaglia, A.; Lanza, C.M.; Napoli, E.M.; Ruberto, G. Emerging cultivation of oregano in Sicily: Sensory evaluation of plants and chemical composition of essential oils. Ind. Crops Prod. 2012, 35, 160-165. [CrossRef]

18. Giannoulis, K.D.; Kamvoukou, C.-A.; Gougoulias, N.; Eleni Wogiatzi, E. Irrigation and nitrogen application affect Greek oregano (Origanum vulgare ssp. hirtum) dry biomass, essential oil yield and composition. Ind. Crops Prod. 2020, 150, 112392. [CrossRef]

19. Król, B.; Sęczyk, L.; Kołodziej, B.; Paszko, T. Biomass production, active substance content, and bioaccessibility of Greek oregano (Origanum vulgare ssp. hirtum (Link) Ietswaart) following the application of nitrogen. nd. Crops Prod. 2020, 148, 112271. [CrossRef]

20. Sotiropoulou, D.E.; Karamanos, A. Field studies of nitrogen application on growth and yield of Greek oregano (Origanum vulgare ssp. hirtum (Link) Ietswaart). Ind. Crops Prod. 2010, 32, 450-457. [CrossRef]

21. Dordas, C. Chlorophyll meter readings, $\mathrm{N}$ leaf concentration and their relationship with $\mathrm{N}$ use efficiency in oregano. J. Plant Nutr. 2017, 40, 391-403. [CrossRef] 
22. Sęczyk, Ł.; Król, B.; Kołodziej, B. In vitro bioaccessibility and activity of Greek oregano (Origanum vulgare L. ssp. hirtum (link) Ietswaart) compounds as affected by nitrogen fertilization. J. Sci. Food Agric. 2020, 100, 2410-2417. [CrossRef] [PubMed]

23. Novak, J.; Grausgruber, H.; Pank, F.; Langbehn, J.; Blóthner, W.D.; Vender, C.; Niekerk, L.V.; Junghanns, W.; Franzl, C. Stability of hybrid combinations of Marjoram (Origanum majorana L.). Flavour Fragr. J. 2003, 18, 401-406. [CrossRef]

24. Dordas, C. Foliar application of calcium and magnesium improves growth, yield, and essential oil yield of oregano (Origanum vulgare ssp. hirtum). Ind. Crops Prod. 2009, 29, 599-608. [CrossRef]

25. Karamanos, A.J.; Sotiropoulou, D.E. Field studies of nitrogen application on Greek oregano (Origanum vulgare ssp. hirtum (Link) Ietswaart) essential oil during two cultivation seasons. Ind. Crops Prod. 2013, 46, 246-252. [CrossRef]

26. Ozgüven, M.; Ayanoglu, F.; Ozel, A. Effects of nitrogen rates and cutting times on the essential oil yield and components of Origanum syriacum L. var. bevanii. J. Agron. 2006, 5, 101-105. [CrossRef]

27. Ninou, E.; Paschalidis, K.; Mylonas, I. Essential oil responses to water stress in Greek oregano populations. J. Essent. Oil Bear. Plants 2017, 20, 12-23. [CrossRef]

28. Omer, A.E. Response of wild Egyptian oregano to nitrogen fertilization in a sandy soil. J. Plant Nutr. 1999, 19, 955-967. [CrossRef]

29. Azizi, A.; Yan, F.; Honermeier, B. Herbage yield, essential oil content and composition of three oregano (Origanum vulgare L.) populations as affected by soil moisture regimes and nitrogen supply. Ind. Crops Prod. 2009, 29, 554-561. [CrossRef]

30. Strid, A.; Tan, K. Flora Hellenica; A.R.G Gantner Verlag K.G., Koeltz Scientific Books: Koenigstein, Germany, 2002 ; Volume 2.

31. Google (n.d.). Royal Roads University. Available online: https://www.google.gr/maps/@38.0804111,25.4721762,746580m/data= !3m1!1e3?hl=el (accessed on 2 July 2021).

32. European Pharmacopoeia (2008). Determination of Essential Oils in Herbal Drugs, 6th ed.; Council of Europe (COE), European Directorate for the Quality of Medicines: Strasbourg, France, 2008; pp. 251-252.

33. IBM Corp. IBM SPSS Statistics for Windows, Version 23.0; IBM Corp.: Armonk, NY, USA, 2015.

34. Goliaris, A. Research and production of medicinal and aromatic plants in Greece. Med. Plant Rep. 1997, 4, 1-11.

35. Kokkini, S.; Vokou, D. Carvacrol-rich plants in Greece. Flavour Fragr. J. 1989, 4, 1-7. [CrossRef]

36. Fehr, W.R. Principles of Cultivar Development; Theory and Technique, Ed.; Macmillan Publishing Company, A Division of Macmillan, Inc.: New York, NY, USA, 1987; Volume 1, p. 10022.

37. Simmonds, N.W. Genotype (G), environment (E) and GE components of crop yields. Exp. Agric. 1981, 17, 355-362. [CrossRef]

38. Kang, M.S. (Ed.) Genotype-Environment Interaction: Progress and Prospects. In Quantitative Genetics, Genomics and Plant Breeding; CABI: Wallingford, UK, 2002; pp. 221-243. 